\title{
Effects of Pregabalin, Nimodipine, and Their Combination in the Inhibition of Status Epilepticus and the Prevention of Death in Mice
}

\section{Epilepsi Durumunun İnhibisyonuna ve Ölümün Önlenmesine Pregabalin, Nimodipin ve Bunların Kombinasyonunun Farelerdeki Etkileri}

\author{
(D) Itefaq QURESHI ${ }^{1}$, (D) Azra RIAZ1, (D) Rafeeq KHAN²*, (D) Moona BAIG¹, (D) Muhammad Ali RAJPUT¹ \\ 1 University of Karachi, Department of Pharmacology, Karachi, Pakistan \\ 2Ziauddin University, Faculty of Pharmacy, Karachi, Pakistan
}

\begin{abstract}
Objectives: The current study aims to evaluate the combined antiepileptic effects of pregabalin (PGB) and nimodipine (NMD) in an acute seizure model of epilepsy in mice.

Materials and Methods: This study assessed the combined antiepileptic effects of PGB with NMD on death protection in mice. Pentylenetetrazole was used to induce seizures. Both drugs were used singly and in combination to judge anticonvulsant effects on an acute seizure model of epilepsy in mice. Diazepam (DZ) and valproate (VPT) were used as standard antiepileptic drugs.

Results: The death protection in mice by both these drugs was observed in percentage and deliberated as marked change when the outcome of the tested drug was equal to $E D_{50}$ of $P G B$ and measured highly marked when the result was more than $E D_{50}$ for $P G B$. Treatment with pregabalin and nimodipine combination revealed substantial mortality protection at $30+2.5 \mathrm{mg} / \mathrm{kg}$ dose and highly marked at doses from $35+5 \mathrm{mg} / \mathrm{kg}$ to $55+15$ $\mathrm{mg} / \mathrm{kg}$, these effects were superior to individual effects of $P G B$, showing synergism, however lesser then classic drugs valproate and diazepam. Conclusion: NMD showed synergistic anticonvulsant effect with PGB. However, clinical studies are required to establish the effectiveness of this combination in humans.
\end{abstract}

Key words: Pregabalin, nimodipine, valproate, diazepam, pentylenetetrazole

öz

Amaç: Bu çalıșma, farelerde akut epilepsi nöbet modelinde pregabalin (PGB) ve nimodipinin (NMD) kombine antiepileptik etkilerini değerlendirmeyi amaçlamaktadır.

Gereç ve Yöntemler: Bu çalıșma, farelerde ölümü önlemek için PGB ve NMD ile kombine antiepileptik etkilerini değerlendirmiștir. Bu çalıșma, farelerde ölümü önlemek için PGB'nin NMD ile kombine antiepileptik etkilerini değerlendirmiștir. Pentilentetrazol nöbetleri indüklemek için kullanılmıştır. Farelerde epilepsinin akut nöbet modeli üzerindeki antikonvülsan etkileri değerlendirmek için her iki ilaç tek başına ve kombinasyon halinde kullanılmıştır. Standart antiepileptik ilaç olarak diazepam (DZ) ve valproat (VPT) kullanılmıştır.

Bulgular: Farelerde bu ilaçların her ikisi tarafından ölüm koruması yüzde olarak gözlemlendi ve test edilen ilacın sonucu $P_{G B}$ 'nin $E D_{50}$ 'sine eșit olduğunda belirgin değişiklik olarak düşünüldü ve sonuç $\mathrm{PGB}$ için $\mathrm{ED}_{50}$ 'den fazla olduğunda oldukça belirgin olarak ölçüldü. Pregabalin ve nimodipin kombinasyonu ile tedavi, $30+2,5 \mathrm{mg} / \mathrm{kg}$ dozda önemli mortalite koruması gösterdi ve $35+5 \mathrm{mg} / \mathrm{kg}$ ila $55+15 \mathrm{mg} / \mathrm{kg}$ dozlarda oldukça belirgindi, bu etkiler PGB'nin bireysel etkilerinden üstündü, ancak sinerjizm gösteriyordu. Klasik ilaçlar valproat ve diazepamdan daha az bulunmuștur.

Sonuç: NMD, PGB ile sinerjistik antikonvülsan etki göstermiştir. Bununla birlikte, bu kombinasyonun insanlarda etkinliğini belirlemek için klinik çalışmalara ihtiyaç vardır.

Anahtar kelimeler: Pregabalin, nimodipin, valproat, diazepam, pentilentetrazol

\footnotetext{
*Correspondence: rkhan1959@gmail.com, Phone: +92103218258742, ORCID-ID: orcid.org/0000-0002-8051-759X

Received: 01.05.2020, Accepted: 25.05.2020

๑Turk J Pharm Sci, Published by Galenos Publishing House.
} 


\section{INTRODUCTION}

Status epilepticus is a severe condition of shared epilepsies. It is a life-threatening neural health crisis, ${ }^{2}$ which may lead to loss of life in many instances if not cured suitably: Lorazepam and diazepam (DZ) are the major drugs of choice for a short period to control status epilepticus. ${ }^{3}$ However, lorazepam has been superior to DZ. ${ }^{4}$ Valproate (VPT), phenobarbitone, and phenytoin are endorsed for the extended period of treatment of status epilepticus. ${ }^{5}$ The selection of first-line drugs is limited to the management of status epilepticus, and the drugs suggested have serious side effects and drug-drug interactions. ${ }^{6,7}$ Nimodipine (NMD) is a voltage-gated calcium channel inhibitor permitted by Food and Drug Administration (FDA) for hypertension since it inhibits the L-type calcium channels in blood vessels. ${ }^{8}$

NMD inhibits and modifies voltage-gated calcium channels in the central nervous system (CNS). ${ }^{9}$ Low and high voltage-gated calcium channels have a crucial role in neuronal functions in major parts of the CNS, embracing excitability.10,11 Hence, it seems appropriate for the calcium-channel blockers (CCBs) to be employed to treat epilepsy.12,13 NMD in several animal studies showed increasing antiepileptic effects over other anticonvulsion drugs, e.g., carbamazepine, VPT, and lamotrigine, in the management of acute seizures. ${ }^{14,15}$ Pregabalin (PGB) is well tolerated, efficient and FDA permitted its use in patients with epilepsy. ${ }^{16,17}$ Its antiepileptic action relates to binding alpha-2-delta voltage-gated calcium channels, including many other pharmacodynamic anti-seizure actions in the CNS.18 The current study aims to evaluate the combined antiepileptic effects of PGB and NMD in an acute seizure model of epilepsy in mice.

\section{MATERIALS AND METHODS}

\section{Animals}

Consent was obtained from the Board of Advanced Studies and Research (BASR) 10 (P) 04 dated June 19, 2015, to conduct the current study at the Department of Pharmacology, University of Karachi. The mice used in the study were managed as per the guidelines of the National Institute of Health. ${ }^{19}$ The ethical approval for the use of animals was granted by the departmental research committee after the letter issued by the BASR dated September 30, 2015 (approval no: BASR/02521). The experiments were performed on male albino mice whose weight ranged from 20 to $25 \mathrm{~g}$. The animals were kept in a controlled environment with regular provisions of food and water. The temperature was sustained at $21^{\circ} \mathrm{C} \pm 2^{\circ} \mathrm{C}$ with 12 -hour light/dark cycles. The animals were exposed to the location for 2-3 days before the experiments could be performed. The tests were done from 9:00 am to 12:30 pm.

\section{Drug treatment}

Acute attacks were induced by pentylenetetrazole (PTZ). Meanwhile, PGB and NMD were used as test drugs. DZ and VPT were employed to equate the antiepileptic effects of the test drugs. Normal saline was used for animals in the control group. The HEJ Research Center, University of Karachi, provided PTZ. DZ and VPT injections were acquired from a local market by Roche Pakistan Ltd. and Abbot Laboratories, Pakistan Ltd, Karachi, respectively. PGB capsules of Getz Pharma Pvt. Limited, Karachi were also obtained from the local market. Novartis Pharma, Pakistan Ltd, Karachi, provided the NMD injections.

PGB, NMD, and PTZ were liquefied in sterile, normal saline. Aluminum foil was used to cover the PTZ solution to avoid disintegration. The solutions were made regularly and used within an hour of their inception. PGB capsule contents were dissolved in sterile water and administer subcutaneously, while other drugs were given by the intraperitoneal route.

\section{Procedure}

Convulsions in all mice were induced via PTZ at a dose of 90 $\mathrm{mg} / \mathrm{kg}$ through subcutaneous administration. ${ }^{20} \mathrm{PGB}$ and NMD were given separately and in combination as six different doses. All drugs, including the test substance and the standard drugs DZ and VPT, were administered 40 minutes earlier than PTZ, administered intraperitoneally. The mice were kept alone following PTZ administration and observed. The prevention of death was recorded in percentage.

The outcomes of mice that remained without seizures up to cut-off time were stated as 0 . The number of mice survived (mortality protection) and died were recorded as a percentage. The anticonvulsant effect, seizure form, and mortality protection achieved by the combination regimen (PGB + NMD + PTZ) in six doses of the test drugs were equated with $P T Z$, individual effects of PGB + PTZ and NMD + PTZ. and with reference drugs (DZ + PTZ and VPT + PTZ).

A period of 60 minutes was the cut-off time for seizure defense after PTZ administration with or without the test drugs. .1-25 $^{1-2}$ The antiepileptic effects of PGB and NMD were assessed by observing seizure prevention as a percentage.

All animals used in this study were distributed into three parts, i.e., $A, B$, and $C$, each part had ten groups, and each group included 12 mice. Group I in each part functioned as control and was given sterile, normal saline; group II mice were given PTZ, and animals in groups III to VIII were given different doses of the test drugs. Mice in groups IX and X were given DZ and VPT. DZ was given at a dose of $7.5 \mathrm{mg} / \mathrm{kg}$ and VPT $100 \mathrm{mg} / \mathrm{kg}$, forty minutes before giving PTZ. Six groups of part-A were given PGB doses ranging from 30 to $55 \mathrm{mg} / \mathrm{kg}$, with a difference of $5 \mathrm{mg} / \mathrm{kg}$ in each group. Animals of part-B were given NMD at doses of $2.5,5,7.5,10,12.5$, and $15 \mathrm{mg} / \mathrm{kg}$. Animals in part-C were given six different combinations of $P G B+N M D$, i.e., $30+2.5,35+5,40+7.5,45+10,50+12.5$, and $55+15 \mathrm{mg} / \mathrm{kg}$, forty minutes before giving PTZ.

\section{Statistical analysis}

No standard statistical procedure was performed in the current study. The results were expressed in percentages and produced a noticeable outcome when the tested drugs were equal to effective dose $50\left(E_{50}\right)$ of $P G B$ and a highly substantial result when the outcome was more than ED50 for PGB. 


\section{RESULTS}

Table 1 summarizes the results of all animals groups in the three sections however Figure 1 shows the results of animals only in section-A. PGB as a single agent in its six doses from 30 to 55 $\mathrm{mg} / \mathrm{kg}$ protected mortality from $42 \%$ to $67 \%$. Both the reference drugs VPT and DZ provided $100 \%$ mortality protection. The antiepileptic effects of PGB, when matched to the reference drugs VPT and DZ, were comparatively inferior in preventing all epileptic attacks.

Table 1 summarizes the results of all animals groups in the three sections however Figure 2 shows the results of animals only in section-B. NMD as a single agent in its first three doses, i.e., $2.5,5$, and $7.5 \mathrm{mg} / \mathrm{kg}$, exhibited $100 \%$ mortality. However, at a dose of $10 \mathrm{mg} / \mathrm{kg}$, the mortality protection was $8 \%$, whereas at doses of $12.5 \mathrm{mg} / \mathrm{kg}$ and $15 \mathrm{mg} / \mathrm{kg}$, the mortality protection was $17 \%$. VPT and DZ prevented death in $100 \%$ of animals. The antiepileptic effect of NMD, when matched to standard drugs VPT and DZ, was highly inferior in all seizure forms.

Table 1. Antiepileptic outcome of pregabalin, nimodipine, and their combination in an acute model of epilepsy

\begin{tabular}{|c|c|c|}
\hline Groups & Doses $\mathrm{mg} / \mathrm{kg}$ & $\begin{array}{l}\text { Mortality } \\
\text { protection }\end{array}$ \\
\hline Normal control & $10 \mathrm{~mL} / \mathrm{kg}$ & 100 \\
\hline PTZ & 90 & 00 \\
\hline PGB & 30 & 42 \\
\hline PGB & 35 & 42 \\
\hline PGB & 40 & $50^{*}$ \\
\hline PGB & 45 & $58^{* *}$ \\
\hline PGB & 50 & $67^{\star *}$ \\
\hline PGB & 55 & $67^{\star *}$ \\
\hline NMD & 2.5 & 00 \\
\hline NMD & 5.0 & 00 \\
\hline NMD & 7.5 & 00 \\
\hline NMD & 10 & 8 \\
\hline NMD & 12.5 & 17 \\
\hline NMD & 15 & 17 \\
\hline PGB:NMD & $30: 2.5$ & $50^{*}$ \\
\hline PGB:NMD & $35: 5$ & $58^{* *}$ \\
\hline PGB:NMD & $40: 7.5$ & $58^{\star *}$ \\
\hline PGB:NMD & $45: 10$ & $67^{\star \star}$ \\
\hline PGB:NMD & $50: 12.5$ & $83^{* \star}$ \\
\hline PGB:NMD & $55: 15$ & $83^{* *}$ \\
\hline VPT & 100 & 100 \\
\hline $\mathrm{DZ}$ & 7.5 & 100 \\
\hline
\end{tabular}

*Marked as compared to $40 \mathrm{mg} / \mathrm{kg} \mathrm{PGB}\left(\mathrm{ED}_{50}\right)$, **Highly substantial as compared to $40 \mathrm{mg} / \mathrm{kg}$ PGB $\left(E_{50}\right)$, n=12, PTZ: Pentylenetetrazole, PGB: Pregabalin, NMD: Nimodipine, VPT: Valproate, DZ: Diazepam, $E_{50}$ : Effective dose 50
Table 1 summarizes the outcomes of all animals groups in the three sections. In contrast, Figure 3 shows the results of animals in section-C. The animals treated in combination dose of $30+2.5$ $\mathrm{mg} / \mathrm{kg}$ PGB and NMD prevented death in 50\%, which was substantial compared with PGB $40 \mathrm{mg} / \mathrm{kg}$. In contrast, animals treated with combination doses of $35+5$ and $40+7.5 \mathrm{mg} / \mathrm{kg}$ PGB and NMD, respectively, showed a $58 \%$ mortality protection. The animals given the combination of PGB and NMD at doses of $45+10 \mathrm{mg} / \mathrm{kg}$ revealed a $67 \%$ mortality protection. However, the maximum mortality protection of $83 \%$ was observed by the combination doses of $50+12.5 \mathrm{mg} / \mathrm{kg}$ and $55+15 \mathrm{mg} / \mathrm{kg}$ of doses of PGB and NMD, respectively.

Table 2 and Figure 4 show the difference in the mortality protection among PGB, NMD, the combination of $P G B+N M D$,

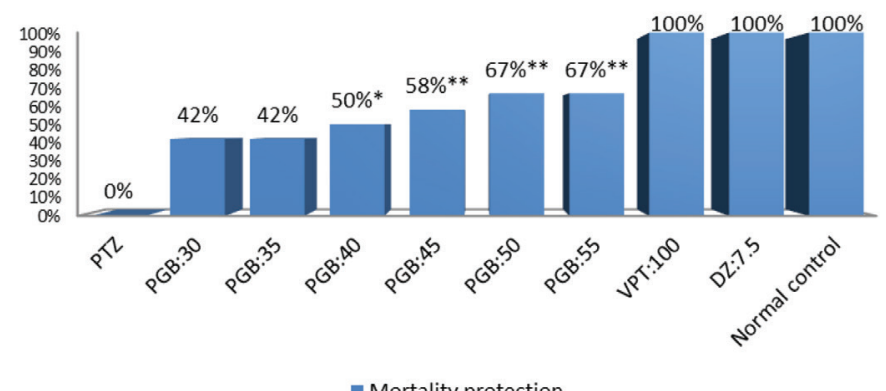

Figure 1. Comparative effects of pregabalin, valproate, and diazepam on mortality protection in an acute model of epilepsy

*Shows marked change and **shows highly substantial change in terms of percentage, PTZ: Pentylenetetrazole, PGB: Pregabalin, VPT: Valproate, DZ: Diazepam

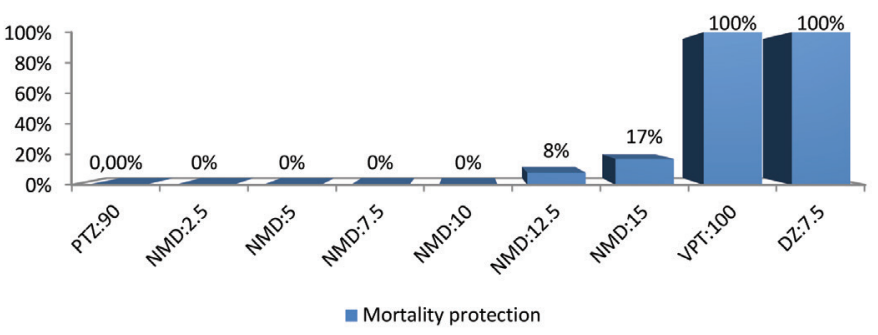

Figure 2. Comparative effects of nimodipine, valproate, and diazepam on the mortality protection in an acute model of epilepsy

PTZ: Pentylenetetrazole, NMD: Nimodipine, VPT: Valproate, DZ: Diazepam

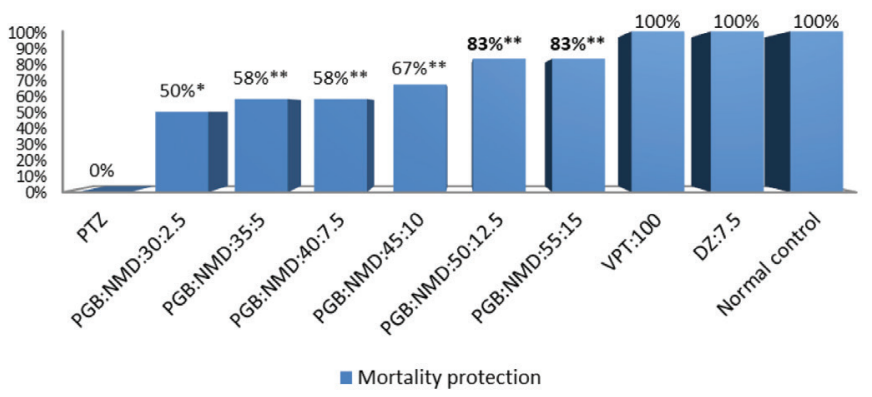

Figure 3. Comparative effects of pregabalin, nimodipine, valproate, and diazepam on the mortality protection in an acute model of epilepsy

*Marked as compared to $40 \mathrm{mg} / \mathrm{kg}$ PGB $\left(E_{50}\right)$, **Highly substantial as compared to $40 \mathrm{mg} / \mathrm{kg}$ PGB $\left(E_{50}\right)$, PTZ: Pentylenetetrazole, NMD: Nimodipine, VPT: Valproate, DZ: Diazepam, $\mathrm{ED}_{50}$ : Effective dose 50 
and VPT. The difference in the mortality protection among NMD in the first three doses and VPT was -100. In contrast, NMD demonstrated a $92 \%$ less mortality protection compared to VPT at $10 \mathrm{mg} / \mathrm{kg}$ and $83 \%$ less mortality protection at 12.5 and $15 \mathrm{mg} / \mathrm{kg}$. PGB demonstrated a 58\% less mortality protection at 30 and $35 \mathrm{mg} / \mathrm{kg}$ doses reduced to $50 \%$ at the dose of $40 \mathrm{mg} / \mathrm{kg}$. While at the dose of $45 \mathrm{mg} / \mathrm{kg}$, a $42 \%$ less mortality protection was noted. However, at 50 and $55 \mathrm{mg} / \mathrm{kg}$ doses, PGB demonstrated $33 \%$ less mortality protection than VPT. The combination of PGB and NMD showed better results in reducing mortality. The difference in mortality protection at doses of $30+2.5 \mathrm{mg} / \mathrm{kg}$ and $35+5 \mathrm{mg} / \mathrm{kg}$ compared with VPT was only $50 \%$, which improved to $42 \%$ at the combination dose of $40+7.5 \mathrm{mg} / \mathrm{kg}$. The difference in the mortality protection improved to $33 \%$ at doses of $45+10 \mathrm{mg} / \mathrm{kg}$ and was reduced to $17 \%$ at the combination doses of $50+12.5 \mathrm{mg} / \mathrm{kg}$ and $55+15 \mathrm{mg} /$ kg compared with VPT.

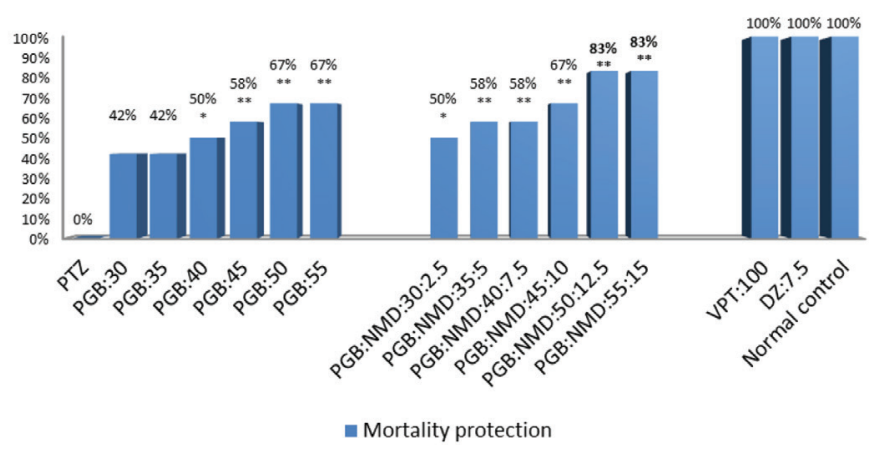

Figure 4. Comparative effects of pregabalin, nimodipine, valproate, and diazepam on the mortality protection in an acute model of epilepsy

*Marked as compared with $40 \mathrm{mg} / \mathrm{kg}$ PGB (ED ${ }_{50}$, **Highly substantial compared with $40 \mathrm{mg} / \mathrm{kg}$ PGB $\left(E_{50}\right)$, PTZ: Pentylenetetrazole, PGB: Pregabalin, NMD: Nimodipine, VPT: Valproate, DZ: Diazepam, ED 50 : Effective dose 50
Table 3 shows the comparisons of the prevention of death for PGB and combinations of PGB and NMD. The PGB and NMD combination at the dose of $30+2.5 \mathrm{mg} / \mathrm{kg}$ demonstrated an $8 \%$ higher prevention of death, whereas the combination dose of $35+5 \mathrm{mg} / \mathrm{kg}$ showed a $16 \%$ higher prevention of death. However, the combination doses of $40+7.5$ and $45+10$ for PGB and NMD demonstrated only $8 \%$ and $9 \%$ prevention of death, respectively. The rate of prevention of death was again consistently higher. It was up to $16 \%$ higher with the doses combination of $50+12$ $\mathrm{mg} / \mathrm{kg}$ and $55+15 \mathrm{mg} / \mathrm{kg}$ of PGB and NMD compared with PGB alone.

\section{DISCUSSION}

Although the discovery of new antiepileptic drugs (AEDs) have widened the selection of drugs to treat epilepsies on a longterm basis, none of the newer AEDs are permitted to treat status epilepticus. Also, the likelihood and usefulness of these new AEDs remain limited, and no AED has been found to retain its best properties. ${ }^{26}$ Exploration of drug combinations that may have the potential to terminate and prevent status epilepticus is the main object of our study. Thus, newer AEDs with better effectiveness and unique mechanisms are now needed to deliver active combinations to treat epilepsy. ${ }^{27}$ Animal models may only be employed to forecast drugs combinations that are effective in the clinical setting. ${ }^{24}$

AEDs may have inhibitory or additive effects. However, drugs possessing additive effects appear to be of medical importance..$^{21,28}$ Therefore, the present investigation evaluated PGB in combination with NMD for synergistic antiepileptic effects in an acute seizure model of epilepsy in mice. It was assumed that a combination of AEDs might potentiate their anticonvulsant effects. This hypothesis was supported by the additive actions of tiagabine and gabapentin. The outcomes

Table 2. Nimodipine, pregabalin, and PGB + NMD in comparison to valproate in the mortality protection in an acute model of epilepsy

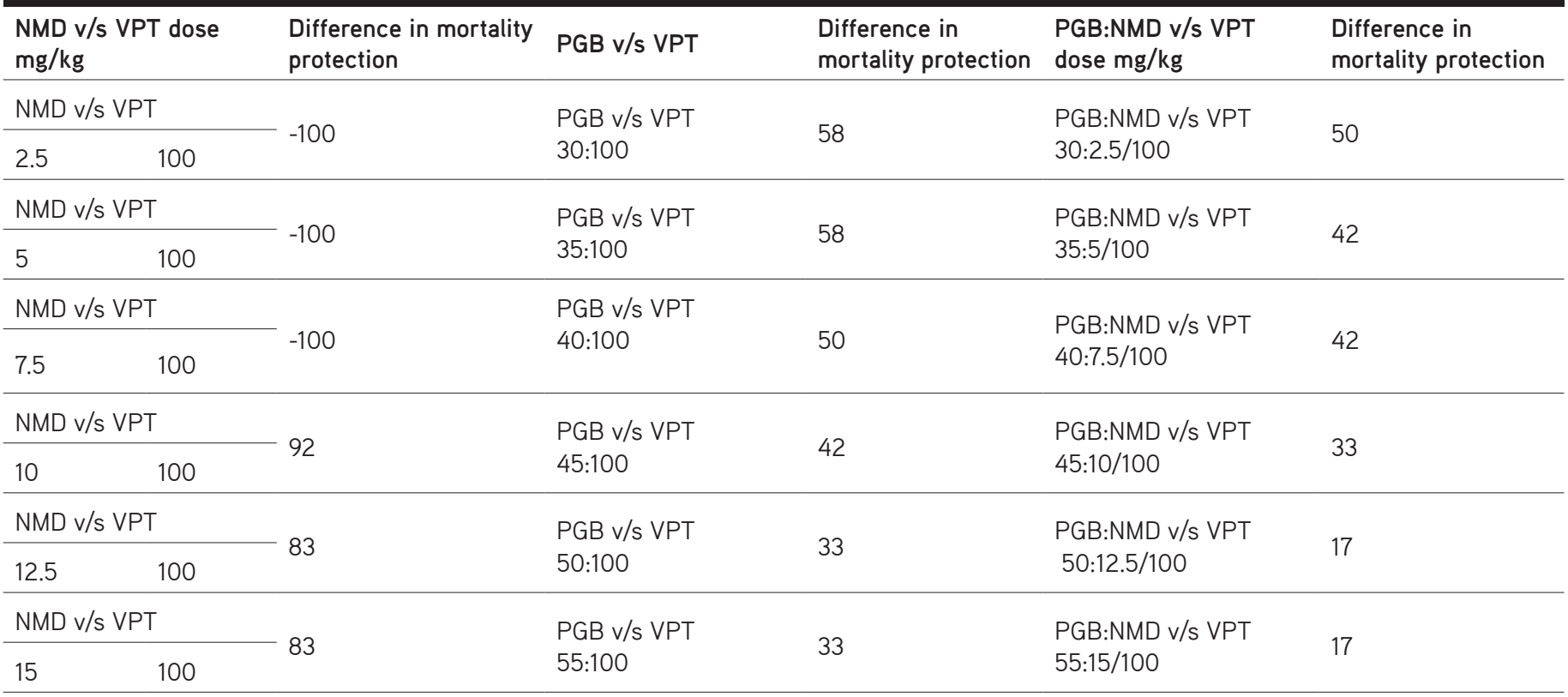

Difference in the mortality protection (\%), PGB: Pregabalin, NMD: Nimodipine, VPT: Valproate 
Table 3. Comparison of the mortality protection pregabalin and PGB + NMD in an acute model of epilepsy

\begin{tabular}{|c|c|c|c|c|}
\hline Treatment groups & Mortality protection & Treatment groups with doses & Mortality protection & Difference in the mortality protection \\
\hline PGB:30 & 42 & $\begin{array}{l}\text { PGB:NMD } \\
30: 2.5\end{array}$ & $50 *$ & 8 \\
\hline PGB:35 & 42 & $\begin{array}{l}\text { PGB:NMD } \\
35: 5\end{array}$ & $58^{* \star}$ & 16 \\
\hline PGB:40 & 50 & $\begin{array}{l}\text { PGB:NMD } \\
40: 7.5\end{array}$ & $58^{* *}$ & 8 \\
\hline PGB:45 & 58 & $\begin{array}{l}\text { PGB:NMD } \\
45: 10\end{array}$ & $67^{\star *}$ & 9 \\
\hline PGB:50 & 67 & $\begin{array}{l}\text { PGB:NMD } \\
50: 12.5\end{array}$ & $83^{* \star}$ & 16 \\
\hline PGB:55 & 67 & $\begin{array}{l}\text { PGB:NMD } \\
55: 15\end{array}$ & $83^{* *}$ & 16 \\
\hline
\end{tabular}

*Marked compared with 40 mg/kg PGB (ED ${ }_{50}$, ,*Highly substantial compared with 40 mg/kg PGB (ED ${ }_{50}$ ), n=12, doses (mg/kg), PGB: Pregabalin, NMD: Nimodipine, $\mathrm{ED}_{50}$ : Effective dose 50

of the present investigation demonstrated that the activation of the neurotransmitters might have produced an additive effect. $^{29}$ In another investigation, the anticonvulsant effects of oxcarbazepine and gabapentin were found to be a mixture of both drugs at the fixed ratios to exert the additive effects against electroconvulsions. ${ }^{30}$

PGB and NMD showed a $50 \%$ prevention of death when given a combination dose of $30+2.5 \mathrm{mg} / \mathrm{kg}$. However, when PGB and NMD were given separately at doses of $30 \mathrm{mg} / \mathrm{kg}$ and 2.5 $\mathrm{mg} / \mathrm{kg}$, the prevention of death was $42 \%$ and $0 \%$, respectively. Hence, there was an $8 \%$ increase in the prevention of death compared with PGB and a 50\% increase compared with NMD alone (Table 1). Similarly, PGB and NMD showed a $58 \%$ prevention of death at the combination dose of $35+5 \mathrm{mg} / \mathrm{kg}$. However, when these drugs were given separately at doses of $35 \mathrm{mg} / \mathrm{kg}$ and $5 \mathrm{mg} / \mathrm{kg}$, the prevention of death was $42 \%$ and $0 \%$, respectively. Therefore, a $16 \%$ increase in the prevention of death compared with PGB and a $58 \%$ increase in the response compared with NMD in PTZ-induced acute seizures (Table 1).

PGB and NMD showed a $67 \%$ prevention of death with the combination dose of $45+10 \mathrm{mg} / \mathrm{kg}$. However, when PGB and NMD were given separately at doses of $45 \mathrm{mg} / \mathrm{kg}$ and $10 \mathrm{mg} / \mathrm{kg}$, the prevention of death was $58 \%$ and $8 \%$, respectively. Hence, there was a $9 \%$ increase in the prevention of death compared with PGB and a 59\% increase in the prevention of death compared with NMD (Table 1). The animal groups received combination doses of $50+12.5 \mathrm{mg} / \mathrm{kg}$ and $55+15 \mathrm{mg} / \mathrm{kg}$ PGB. NMD exhibited maximum anticonvulsant effects with an $83 \%$ prevention of death. This was $17 \%$ and $67 \%$ more than the individual response to $P G B$ and NMD, respectively. Hence, synergistic effects have been observed at all the combination doses of PGB and NMD. Thus, the combination regimen decreased the $\mathrm{ED}_{50}$ of the PGB from $40 \mathrm{mg} / \mathrm{kg}$ to $30 \mathrm{mg} / \mathrm{kg}$. The decrease in $E_{50}$ was $10 \mathrm{mg} /$ $\mathrm{kg}$, which was a $25 \%$ decrease in the $E D_{50}$ of the $P G B$ in the treatment of acute seizures in mice (Table 1). This shows that adding the CCB NMD with PGB exerted remarkable synergistic anti-seizure effects by increasing the mortality protection but not abolishing the seizures completely.

The pharmacokinetic and pharmacodynamic profiles of PGB reveal it to be a well-tolerated drug. ${ }^{17,31,32}$ The FDA has recognized it for the treatment of epilepsy. ${ }^{33,34} \mathrm{PGB}$ in several investigations has validated its value for the treatment of partial and generalized seizures. PGB has also shown its effectiveness in refractory epilepsy, and combination treatment may have a broader range to manage many forms of convulsions. ${ }^{16}$ In this study, we anticipated that the antiepileptic actions of PGB could be amplified or altered when administered in combination with NMD. Calcium channel antagonists retain anticonvulsant effects in experimental models and enhance the guarding activity of some AEDs. ${ }^{35} \mathrm{NMD}$ is a dihydropyridine calcium channel antagonist that blocks $\mathrm{N}$-and $\mathrm{P} / \mathrm{Q}$-type calcium channels, with greater affinity for both channels. ${ }^{36,37}$ Numerous investigations have shown important augmented anticonvulsant actions of amlodipine and NMD on topiramate, VPT, phenobarbitone, and other AEDs. 15,30,38 Thus, there are convincing reasons illustrating that this investigation provides an essential medical perspective. PGB as monotherapy in acute studies showed marginal to moderate effects on the prevention of death. The effects were inferior compared with the efficacy of VPT and DZ at all test doses. No doses of PGB as monotherapy in acute studies demonstrated a $100 \%$ prevention of death against PTZ. Moreover, the prevention of death with PGB monotherapy in the present study was dose-dependent. PGB demonstrated minimum prevention of death of $42 \%$ at 30 and $35 \mathrm{mg} / \mathrm{kg}$, which was $58 \%$ less than both reference drugs. The prevention of death was enhanced to $50 \%$ at $40 \mathrm{mg} / \mathrm{kg}, 50 \%$ less than VPT and DZ. The maximum prevention of death of $67 \%$ by PGB was observed at the doses of 50 and $55 \mathrm{mg} / \mathrm{kg}$ in acute seizures but was $33 \%$ less than both reference drugs. The efficacy of PGB in acute seizures was $42 \%$ to $67 \%$ compared with the efficacy of VPT (Table 1, Figure 4). 
Low-voltage-gated calcium channels have a wide distribution throughout the CNS and contribute to major processes like neuronal excitability and synaptic transmission. ${ }^{39}$ Among the dihydropyridines, NMD blocks both the L- and T-type calcium channels. ${ }^{40}$ The present study results suggest that the CCB NMD had some involvement in reducing seizures and the death rate, probably by inhibiting T-type low-voltage calcium channels. Therefore, the combination of PGB and NMD revealed greater antiepileptic activity compared with their individual effects at the same doses.

\section{CONCLUSION}

The antiepileptic combination used in the current study demonstrated marked seizure protection overall. However, PGB and NMD at the combination dose of $50+12.5 \mathrm{mg} / \mathrm{kg}$ showed maximum prevention of death, which was $83 \%$. Therefore, it may be concluded that the CCB NMD exhibited anticonvulsant effects by potentiating the antiepileptic effects of PGB in the combination. The primary clinical importance of combination therapies would be a reduction in PGB doses with several times increase in efficacy.

The present study results provide clear evidence that the combination of PGB and NMD provides a better option to treat status epilepticus and typical and atypical epilepsies. The combination of PGB and NMD may have substantial potential to treat diverse types of epilepsies comprising resistant epilepsies due to channel-modifying effects. The major advantage of combination therapy would be the low doses of PGB with better anti-seizure effects. The essential point of this study is the use of combination regimens of PGB/NMD for the short- and longterm control of status epilepticus. However, this may require further animal and clinical studies.

Conflict of interest: No conflict of interest was declared by the authors. The authors are solely responsible for the content and writing of this paper.

\section{REFERENCES}

1. Hauser WA. Status epilepticus: frequency, etiology, and neurological sequelae. Adv Neurol. 1983;34:3-14.

2. Aminoff MJ, Simon RP. Status epilepticus: causes, clinical features and consequences in 98 patients. Am J Med. 1980;69:657-666.

3. Delgado-Escueta AV, Bajorek JG. Status epilepticus: mechanisms of brain damage and rational management. Epilepsia. 1982;23:S29-S41.

4. Alldredge BK, Gelb AM, Isaacs SM, Corry MD, Allen F, Ulrich S, Gottwald MD, O'Neil N, John M. Neuhaus JM, Segal MR and Lowenstein DH. A Comparison of Lorazepam, Diazepam, and Placebo for the Treatment of Out-of-Hospital Status Epilepticus. N Engl J Med. 2001;345:631-637.

5. Brophy GM, Bell R, Claassen J, Alldredge B, Bleck TP, Glauser T, Treiman DM. Guidelines for the evaluation and management of status epilepticus. Neurocrit Care. 2012;17:3-23.

6. Holopainen IE. Seizures in the developing brain: cellular and molecular mechanisms of neuronal damage, neurogenesis and cellular reorganization. Neurochem Int. 2008;52:935-947.
7. Shin HW, Davis R. Review of levetiracetam as a first line treatment in status epilepticus in the adult patients - what do we know so far? Front Neurol. 2013;4:111.

8. Triggle DJ. Calcium channel antagonists: clinical uses--past, present and future. Biochem Pharmacol. 2007;74:1-9.

9. Zapater P, Javaloy J, Román JF, Vidal MT, Horga JF. Anticonvulsant effects of nimodipine and two novel dihydropyridines (PCA 50922 and PCA 50941) against seizures elicited by pentylenetetrazole and electroconvulsive shock in mice. Brain Res. 1998;796:311-314.

10. Khosravani H, Zamponi GW. Voltage-gated calcium channels and idiopathic generalized epilepsies. Physiol Rev. 2006;86:941-966.

11. Iftinca MC, Zamponi GW. Regulation of neuronal T-type calcium channels. Trends Pharmacol Sci. 2009;30:32-40.

12. Knake S, Hamer HM, Rosenow F. Status epilepticus: A critical review. Epilepsy Behav. 2009;15:10-14.

13. Zamponi GW, Lory P, Perez-Reyes E. Role of voltage-gated calcium channels in epilepsy. Pflugers Arch. 2010;460:395-403.

14. Luszczki JJ, Trojnar MK, Trojnar MP, Kimber-Trojnar Z, Szostakiewicz B, Zadrozniak A, Borowicz KK, Czuczwar SJ. Effects of three calcium channel antagonists (amlodipine, diltiazem and verapamil) on the protective action of lamotrigine in the mouse maximal electroshockinduced seizure model. Pharmacol Rep. 2007;59:672-682.

15. Kamiński RM, Mazurek M, Turski WA, Kleinrok Z, Czuczwar SJ. Amlodipine enhances the activity of antiepileptic drugs against pentylenetetrazoleinduced seizures. Pharmacol Biochem Behav. 2001;68:661-668.

16. Ryvlin P, Perucca E, Rheims S. Pregabalin for the management of partial epilepsy. Neuropsychiatr Dis Treat. 2008;4:1211-1224.

17. Toth C. Pregabalin: latest safety evidence and clinical implications for the management of neuropathic pain. Ther Adv Drug Saf. 2014;5:38-56.

18. Beydoun A, Uthman BM, Kugler AR, Greiner MJ, Knapp LE, Garofalo EA. Pregabalin 1008-009 study group. Safety and efficacy of two pregabalin regimens for add-on treatment of partial epilepsy. Neurology. 2005;64:475-480.

19. Council NR. Guide for the Care and Use of Laboratory Animals. $8^{\text {th }}$ ed. The National Academic Press: Washington, DC;2011:6-47.

20. Mandhane SN, Aavula K, Rajamannar T. Timed pentylenetetrazol infusion test: a comparative analysis with s.c.PTZ and MES models of anticonvulsant screening in mice. Seizure. 2007;16:636-644.

21. Stafstrom CE. Mechanisms of action of antiepileptic drugs: the search for synergy. Curr Opin Neurol. 2010;23:157-163.

22. Rubio C, Rubio-Osornio M, Retana-Márquez S, Verónica Custodio ML, $\mathrm{Paz}$ C. In vivo experimental models of epilepsy. Cent Nerv Syst Agents Med Chem. 2010;10:298-309.

23. Loscher W. Critical review of current animal models of seizures and epilepsy used in the discovery and development of new antiepileptic drugs. Seizure. 2011;20:359-368.

24. Kandratavicius L, Balista PA, Lopes-Aguiar C, Ruggiero RN, Umeoka EH, Garcia-Cairasco N, Bueno-Junior LS, Leite JP. Animal models of epilepsy: use and limitations. Neuropsychiatr Dis Treat. 2014;10:16931705.

25. Grone BP and Baraban SC. Animal models in epilepsy research: legacies and new directions. Nat Neurosci. 2015;18:339-343.

26. Franco V, French JA, Perucca E. Challenges in the clinical development of new antiepileptic drugs. Pharmacol Res. 2016;103:95-104. 
27. Moshe SL, Perucca E, Ryvlin P, Tomson T. Epilepsy: new advances. Lancet. 2015;385:884-898.

28. Czuczwar SJ, Borowicz KK. Polytherapy in epilepsy: the experimental evidence. Epilepsy Res. 2002;52:15-23.

29. Luszczki JJ, Czuczwar SJ. Isobolographic profile of interactions between tiagabine and gabapentin: A preclinical study. Naunyn-Schmiedeberg's Arch Pharmacol. 2004;369:434-446.

30. Luszczki JJ. Interactions of tiagabine with ethosuximide in the mouse pentylenetetrazole-induced seizure model: an isobolographic analysis for non-parallel dose-response relationship curves. NaunynSchmiedeberg's Arch Pharmacol. 2008;378:483-492.

31. Shneker BF, McAuley JW. Pregabalin: A new neuromodulator with broad therapeutic indications. Ann Pharmacother. 2005;39:2029-2037.

32. Sills GJ. The mechanisms of action of gabapentin and pregabalin. Curr Opin Pharmacol. 2006;6:108-113.

33. Arroyo S, Anhut H, Kugler AR, Lee CM, Knapp LE, Garofalo EA, Messmer S. Pregabalin add-on treatment: a randomized, double-blind, placebocontrolled and dose-response study in adults with partial seizures. Epilepsia. 2004;45:20-27.
34. Frampton JE, Foster $\mathrm{RH}$. Pregabalin: in the treatment of postherpetic neuralgia. Drugs. 2005;65:111-118; discussion 119-120.

35. Bian F, Li Z, Offord J, Davis MD, McCormick J, Taylor CP, Walker LC. Calcium channel alpha 2-delta type 1 subunit is the major binding protein for pregabalin in neocortex, hippocampus, amygdala, and spinal cord: an ex vivo auto-radiographic study in alpha 2-delta type 1 genetically modified mice. Brain Res. 2006;1075:68-80.

36. Asconape JJ. Some common issues in the use of antiepileptic drugs. Semin Neurol. 2002;22:27-39.

37. Kulak W, Sobaniec W, Wojtal K, Czuczwar S. Calcium modulation in epilepsy. Pol J Pharmacol. 2004;56:29-41.

38. Khanna N, Bhalla S, Verma V and Sharma KK. Modulatory effects of nifedipine and nimodipine in experimental convulsions. Indian $J$ Pharmacol. 2000;32:347-352.

39. Rajakulendran S, Hanna MG. The Role of Calcium Channels in Epilepsy. Cold Spring Harb Perspect Med. 2016;6:a022723.

40. Kopecky BJ, Liang R, Bao J. T-type Calcium Channel Blockers as Neuroprotective Agents. Pflugers Arch. 2014;466:757-765. 